\title{
Runt-Related Transcription Factor 3
}

National Cancer Institute

\section{Source}

National Cancer Institute. Runt-Related Transcription Factor 3. NCI Thesaurus. Code C91790.

Runt-related transcription factor $3(415 \mathrm{aa}, \sim 44 \mathrm{kDa})$ is encoded by the human RUNX3 gene. This protein is involved in the modulation of transcription. 